\title{
HUBUNGAN PREEKLAMPSIA DENGAN KEJADIAN BAYI BERAT LAHIR RENDAH DI KOTA MAKASSAR
}

Preeclampsia Relationship With The Incidence Of Baby Birth Low In Makassar City

\author{
Muhasidah, Herman Djewarut, Sumira, Nuraeni Jalil \\ Polytechnic of Health, Ministry of Health Makassar \\ *) muhasidah@gmail.com
}

\begin{abstract}
The influence of preeclampsia in pregnant women varies from mild hypertension, severe hypertension or hypertensive crisis, eclampsia to HELLP syndrome (Hemolysis, Elevated Liver Enzyme, Low Platelet), the condition of this severe preeclampsia can occur in \pm 1 per 1000 pregnancies. While the impact of this disorder on the fetus also varies from premature birth, obstructed fetal growth that can occur in 1 of 3 cases of preeclampsia to fetal death. This study aims to determine the preeclampsia relationship with the genesis of low birth weight babies. Type of retrospective research, with a cross-sectional study draft. The number of samples in this study was 47 people obtained using Simple Random Sampling according to the criteria of the present sample. Test analysis using the ChiSquare Test statistical analysis (Chi-squared) based on Pearson Correlation Chi-Square with the provisions of Interval Confidence (confidence level) 95\%, Probability (fault tolerance) $5 \%(\alpha=0.05)$. The results showed a preeclampsia relationship with the low birth weight incident. Acquired $\rho$-value value of 0.002 smaller than $\alpha=0.05$. It is expected for mothers with preeclampsia should routinely be checked in to nearby medical personnel to be taken steps-prevention of preeclampsia.
\end{abstract}

Keywords : LBBW, Mom, Pre-eclampsia

\section{ABSTRAK}

Pengaruh preeklampsi pada ibu hamil bervariasi dari hipertensi ringan, hipertensi berat atau krisis hipertensi, eklampsia sampai sindroma HELLP (Hemolysis, Elevated Liver Enzyme, Low Platelet), kondisi preeklampsi berat ini dapat terjadi pada \pm 1 per 1000 kehamilan.Sedangkan dampak kelainan ini pada janin juga bervariasi dari kelahiran prematur, pertumbuhan janin terhambat yang dapat terjadi pada 1 dari 3 kasus preeklampsi sampai kematian janin. Penelitian ini bertujuan untuk mengetahui Hubungan Preeklampsia dengan Kejadian Bayi Berat Lahir Rendah. Jenis penelitian retrospektif, dengan rancangan cross sectional study. Jumlah sampel dalam penelitian ini adalah sebanyak 47 orang yang didapatkan dengan menggunakan Simple Random Samplingsesuai dengan kriteria sampel yang telah ditetapkan. Analisis uji menggunakan analisis statistik Chi Square Test (Chi Kuadrat) berdasarkan Pearson Correlation Chi Square dengan ketentuan Interval Confidence (taraf keyakinan) 95\%, Probability (toleransi kesalahan) $5 \%(a=0,05)$. Hasil penelitian menunjukkan terdapat hubungan Preeklampsia dengan Kejadian Berat Badan Lahir Rendah.Diperoleh nilai $\rho$-value sebesar 0,002 yang lebih kecil dari $a=0,05$. Diharapkan bagi ibu dengan preeklampsi hendaknya rutin memeriksakan diri ke tenaga medis terdekat agar dapat diambil langkah langkah pencegahan terjadinya preeklampsia.

Kata kunci :BBLR, Ibu, Pre-eklampsia

\section{PENDAHULUAN}

Kemampuan menyelenggarakan pelayanan kesehatan suatu bangsa diukur dengan menentukan tinggi rendahnya angka kematian ibu dan bayi, di samping berbagai indikator lainnya seperti angka kesakitan dan status gizi. Dalam program kesehatan, kematian ibu dan bayi sangatlah penting diketahui karena dapat memberikan gambaran status kesehatan masyarakat, gizi, pelayanan kesehatan utamanya ibu hamil, melahirkan dan masa nifas serta kemampuan ekonomi maupun tingkat pendidikan masyarakat (Manuaba, 2010).

Pengaruh preeklampsi pada ibu hamil bervariasi dari hipertensi ringan, hipertensi berat atau krisis hipertensi, eklampsia sampai sindroma HELLP (Hemolysis, Elevated Liver Enzyme, Low Platelet), kondisi preeklampsi berat ini dapat terjadi pada \pm 1 per 1000 kehamilan. Sedangkan dampak kelainan ini pada janin juga bervariasi dari kelahiran prematur, pertumbuhan janin terhambat yang dapat terjadi pada 1 dari 3 kasus preeklampsi sampai kematian janin.Sehingga preeklampsi selain dapat meningkatkan angka morbiditas dan mortalitas yang merupakan cermin kesejahteraan suatu bangsa preeklampsi ini juga membawa dampak masalah sosial yang besar untuk masyarakat (Auer et al., 2010).

Pada satu dekade terakhir adanya disfungsi endotel diduga sebagai penyebab terjadinya preeklampsi. Perubahan profil lipid dapat menyebabkan disfungsi endotel sehingga menyebabkan terjadinya preeklampsi, profil lipid ini diantaranya adalah perubahan Low density lipoprotein (LDL) dan High density Lipoprotein (HDL). Diduga terdapat hubungan antara preeklampsi 
dengan peningkatan rasio Low density lipoprotein dan High density lipoprotein (Williams et al., 2010). Peningkatan rasio Low density lipoprotein dan High density lipoprotein ini menyebabkan terjadinya disfungsi endotel dan aterosklerosis. Pada disfungsi endotel terjadi ketidakseimbangan produksi zat zat yang bertindak sebagai vasodilator seperti prostasiklin dan nitrat oksida dibandingkan dengan vasokonstriktor seperti tromboxan dan endotelium I sehingga akan terjadi vasokonstriksi yang luas dan terjadilah preeklamsi (Cunningham et al., 2010).

Salah satu langkah dalam pencapaian target Millenium Development Goals (MDGs) ke 4 adalah menurunkan kematian anak menjadi $2 / 3$ bagian dari tahun 1990 sampai 2015. Berdasarkan Survei Kesehatan Rumah Tangga (SKRT), Studi Mortalitas dan Riset Kesehatan Dasar dari tahun ke tahun diketahui bahwa preeklampsia masih menjadi penyebab bayi premature maupun IUGR dengan status social ekonomi rendah, kurang gizi, anemia, penyakit ibu, toksemia gravidarum, perawatan antenatal yang kurang adekuat, adiksi obat, komplikasi obstetric dan riwayat insufisiensi reproduksi ibu. Menurut Dowshens kondisi yang memungkinkan kelahiran premature dan keterlambatan pertumbuhan janin antara lain karena adanya kehamilan ganda, kelainan structural mulut rahim, perdarahan, hipertensi karena kehamilan ibu baik karena preklampsia maupun eklampsi dan factor usia ibu kurang dari 20 tahun atau lebih dari 40 tahun.

$\mathrm{Di}$ seluruh dunia preeklampsia menyebabkan 50.000 - 76.000 kematian maternal dan 900.000 kematian perinatal setiap tahunnya.Insiden preeklampsi pada kehamilan adalah sebesar $\pm 5-10 \%$ dan menjadi satu dari tiga penyebab utama angka kematian ibu setelah perdarahan dan infeksi.

Angka kejadian di Indonesia bervariasi di beberapa rumah sakit di seluruh Indonesia yaitu antara $5,75-9,17 \%$ dan meningkat sebesar $40 \%$ selama beberapa tahun terakhir di seluruh dunia. Di Indonesia masih merupakan penyebab kematian nomor dua tertinggi (24\%) setelah perdarahan (Depkes Rl,2011).Dari seluruh kematian bayi di Indonesia, sebanyak $57 \%$ meninggal pada masa bayi baru lahir (usia dibawah 1 tahun), setiap 6 menit terdapat 1 bayi baru lahir yang meninggal. Penyebab kematian bayi baru lahir di Indonesia sebanyak 29\% disebabkan kerena berat badan bayi rendah.

Berdasarkan data dari wordpress Sulawesi Selatan (2010), Di Sulawesi Selatan pada tahun 2007 tercatat bahwa jumlah bayi dengan berat badan lahir rendah sebanyak 2.416 (1.56\% dari total bayi lahir) dan tertangani sebanyak 2.451 orang $(100 \%)$. Pada tahun 2008 jumlah bayi dengan BBLR mengalami penurunan menjadi $1.998(1.36 \%$ dari total jumlah bayi lahir). Pada tahun 2013 terdapat
518 bayi yang meninggal dan sebanyak 82 bayi atau $15.83 \%$ bayi yang meninggal disebabkan oleh BBLR.

Kota Makassar merupakan salah satu sarana pelayanan kesehatan ibu dan bayi yang mempunyai rawat jalan, dan rawat inap persalinan normal. Berdasarkan data yang tercatat dan diperoleh dari rekam medik pada tahun 2014jumlah yang melahirkan dengan preeklampsia sebanyak 89 orang danbayi dengan berat badan lahir rendah sebanyak 51 orang $(57,30 \%)$. Pada tahun 2015jumlah yang melahirkan dengan preeklampsia sebanyak 251 dan bayi dengan berat badan lahir rendah sebanyak 185 orang (75.29\%). Pada bulan Januari-Maret 2016 jumlah yang melahirkan preeklampsia sebanyak 66 orang bayi dengan berat badan lahir rendah sebanyak 15 orang $(75.29 \%)$.

\section{METODE}

Jenis penelitian yang digunakan adalah penelitian retrospektif yang bertujuan untuk memperoleh faktor-faktor yang mempengaruhi hubungan pre eklampsia dengan kejadian bayi berat lahir rendah (BBLR), dengan menggunakan pendekatan cross sectional study di mana peneliti melakukan pengukuran variable (subjek hanya diobservasi satu kali dan pengukuran variable subjek dilakukan pada saat pemeriksaan tersebut).

Penelitian ini dilaksanakan di Kota Makassar. Penelitian ini di laksanakan pada bulan Juni tahun 2016.

Peneliti mengambil populasi sebanyak 66 orang ibu yang melahirkan dengan preeklampsia di rekam medik (data sekunder). Peneliti mengambil sampel sebanyak 47 orang ibu yang melahirkan preeklampsia di rekam medik (data sekunder). Adapun kriteria sampel yaitu : Ibu yang melahirkan dengan preeklampsia, lbu yang melahirkan dengan BBLR dan lbu yang bersedia menjadi responden.Teknik pengambilan sampel yang digunakan adalah random sampling yaitu pemilihan sample secara acak atau undian, dimana tiap unsur yang membentuk populasi diberi kesempatan yang sama untuk terpilih menjadi sampel (Saryono, 2013).

Cara undian dilakukan dengan menggunakan prinsip-prinsip undian, yaitu : Peneliti mendaftar semua anggota populasi.Setelah selesai didaftar, kemudian masing-masing anggota populasi diberi nomor, masing-masing dalam satu kertas kecilkecil. Kertas-kertas kecil yang masing-masing telah diberi nomor tersebut kemudian digulung. Gulungan tersebut yang telah berisi nomor-nomor tersebut, kemudian dimasukkan kedalam wadah misalkan kotak atau kaleng yang dapat digunakan untuk mengaduk sehingga menjadi acak. Setelah proses pengadukan dianggap sudah merata, kemudian peneliti atau orang lain yang diawasi peneliti, 
mengambil gulungan kertas satu per satu sampai diperoleh sejumlah sampel yang diperlukan.

HASIL

Berdasarkan hasil penelitian yang dilaksanakan di Kota Makassar padatahun 2016 dengan jumlah sampel 47 orang diperoleh hasil berikut ini.

AnalisisUnivariat

Tabel 1

Distribusi Frekuensi Berdasarkan Umur lbu Di Kota Makassar

\begin{tabular}{crc}
\hline Umurn \% & & \\
\hline 20-30 tahun & 17 & 36,2 \\
$31-40$ tahun & 25 & 53,2 \\
$41-50$ tahun & 5 & 10,6 \\
\hline Total & 47 & 100 \\
\hline Sumber : Data Primer \\
Tabel 1 menunjukkan bahwa dari 47 \\
responden, umur ibu 20-30 tahun sebanyak 17 \\
responden (36.2\%), umur ibu 31-40 tahun sebanyak \\
25 responden (53.2\%), umur ibu 41-50 tahun \\
sebanyak 5 responden (10.6\%). Jadi umur \\
responden lebih banyak pada kelompok umur 31-40
\end{tabular}
tahun.

Tabel 2

Distribusi Frekuensi Berdasarkan Pendidikan lbu Di Kota Makassar

\begin{tabular}{crr}
\hline Pendidikan & $\mathbf{n}$ & \multicolumn{1}{c}{} \\
\hline SD & 5 & 10,6 \\
SMP & 2 & 4,3 \\
SMA & 24 & 51,5 \\
D3 & 4 & 8,5 \\
S1 & 12 & 25,5 \\
\hline Total & 47 & 100 \\
\hline
\end{tabular}

Sumber : Data Primer

Berdasarkan tabel 2 dari 47 responden menunjukkan bahwa pendidikan SD sebanyak 5 responden (10.6\%), SMP sebanyak 2 responden $(4.3 \%)$, dan SMA sebanyak 24 responden $(51.5 \%)$, D3 sebanyak 4 responden (8.5\%) dan S1 sebanyak 12 responden (25.5\%). Jadi pendidikan responden lebih banyak pada kelompok SMA.

Tabel 3

Distribusi Frekuensi Berdasarkan Preklampsia Di Kota Makassar

\begin{tabular}{ccc}
\hline Preklampsia & $\mathbf{n}$ & $\%$ \\
\hline Berat & 26 & 55,3 \\
Ringan & 21 & 44,7 \\
\hline Total & 47 & 100 \\
\hline
\end{tabular}

Sumber : Data Primer

Berdasarkan tabel 3 dari 47 responden menunjukkan bahwa ibu yang mengalami preeklampsia berat sebanyak 26 responden $(55,3 \%)$, sedangkan yang tidak preeklampasia ringan sebanyak 21 responden $(44,7 \%)$.

\begin{tabular}{l}
\hline \multicolumn{4}{c}{ Tabel 4 } \\
Distribusi Frekuensi Berdasarkan Bayi Baru Lahir \\
Di Kota Makassar
\end{tabular}

Analisis Bivariat

Tabel 5

Distribusi Hubungan Preeklampsia dengan

Kejadian Bayi Baru Lahir Rendah Di Kota Makassar Tahun 2018

\begin{tabular}{|c|c|c|c|c|c|c|c|}
\hline \multirow{3}{*}{$\begin{array}{c}\text { Pre } \\
\text { eklampsia }\end{array}$} & \multicolumn{4}{|c|}{ BBL } & \multirow{2}{*}{\multicolumn{2}{|c|}{ Jumlah }} & \multirow{3}{*}{$\alpha=0,05$} \\
\hline & \multicolumn{2}{|c|}{ BBLR } & \multicolumn{2}{|c|}{ BBLSR } & & & \\
\hline & $n$ & $\%$ & $n$ & $\%$ & $\mathrm{n}$ & $\%$ & \\
\hline Berat & 21 & 80.8 & 5 & 19.2 & 26 & 100 & \multirow{3}{*}{$\begin{array}{c}\rho= \\
0,002\end{array}$} \\
\hline Ringan & 8 & 38.1 & 13 & 61.9 & 21 & 100 & \\
\hline Jumlah & 29 & 61.7 & 18 & 38.3 & 47 & 100 & \\
\hline
\end{tabular}

Sumber : Data Primer

Berdasarkan Data tabel 5, menunjukkan bahwa ibu yang mengalami preeklampsia berat dan melahirkan bayi berat lahir rendah (BBLR) sebanyak 21 orang $(80.8 \%)$, dan ibu yang mengalami preeklampsia berat melahirkan bayi berat lahir sangat rendah (BBLSR) sebanyak 5 orang $(19.2 \%)$, sedangkan ibu yang mengalami preeklampsia ringan melahirkan bayi berat lahir rendah (BBLR) sebanyak 8 orang (38.1\%), dan ibu yang mengalami preeklampsia ringan melahirkan bayi berat lahir sangat rendah (BBLSR) sebanyak 13 orang (61.9\%).

\section{PEMBAHASAN}

Analisis uji menggunakan analisis statistik Chi Square Test (Chi Kuadrat) berdasarkan pearson correlation chi squa dengan ketentuan Interval Confidence (taraf keyakinan) 95\%, Probability (toleransi kesalahan) $5 \%(a=0,05)$. Hasil penelitian menunjukkan terdapat hubungan Preeklampsia dengan Kejadian Berat Badan Lahir Rendah dan dengan diperoleh nilai $\rho$-value sebesar 0,002 yang lebih kecil dari $\alpha=0,05$

Hasil Penelitan Hubungan Preeklampsia dengan Kejadian Bayi Berat Lahir Rendah di Kota Makassar, Berdasarkan pembahasan diatas berarti ada hubungan preeklampsia dengan kejadian bayi berat lahir rendah dimana BBLR bisa di sebabkan oleh preeklampsia yang merupakan salah satu komplikasi yang terjadi saat kehamilan (Glover). Preeklampsia dapat menyebabkan terjadunya BBLR, tekanan darah tinggi yang mengakibatkan penurunan zat asam yang mengalir dari ibu dan ke janin yang 
dikandung melalui plasenta, menurunnya aliran darah ke plasenta mengakibatkan gangguan fungsi plasenta sehingga pertumbuhan janin akan terganggu sehingga menyebabkan bayi dapat lahir dengan BBLR (Manuaba, 2010)).

Hal ini sesuai penelitiantentang Hubungan antara preklampsia pada primigravida dengan berat badan lahir rendah di RSUD Cilacap yaitu besar sampel yang diperoleh adalah 335 responden dimana ditemukan ibu yang menderita preklampsia dan melahirkan BBLR sebanyak $51,9 \%$ dan yang tidak melahirkan BBLR sebanyak 40,1\%.(Yuniet al, 2006)

Hal ini sejalan dengan menurut Manuaba (2010) yaitu etiologi dari bayi baru lahir rendah salah satunya adalah preklampsia yang merupakan komplikasi dari kehamilan. Menurut Prawirohardjo preklampsia menyebabkan perubahan anatomipatologik yang terjadi pada plasenta dan uterus yaitu cairan darah dan uterus menurun dan menyebabkan gangguan pada plasenta sehingga terjadi gangguan pertumbuhan pada janin dan kekurangan oksigen dan dapat terjadi gawat janin(Badriyah \& Tjahyani, 2013). Hasil penelitian ini sejalan dengan hasil penelitian Suwoyo (2011) Hubungan Preeklampsia Berat Pada Kehamilan Dengan Kejadian BBLR Di RSUD Dr.Hardjono Ponorogo Tahun 2010.Dengan demikian asumsi peneliti memperoleh hasil bahwa sebagian besar ibu dengan diagnosa preeklampsia melahirkan bayi dengan berat badan lahir rendah dibanding ibu normal, karena kita ketahui gejala preeklampsia berat (PEB) adalah tekanan darah tinggi,edema, dan proteinuria yang dapat memicu kejadian bayi berat lahir rendah.

Salah satu cara yang efektif untuk menurunkan angka kematian perinatal adalah mencegah terjadinya BBLR yaitu dengan cara melakukan pengawasan kehamilan dengan seksama dan teratur,melakukan konsultasi terhadap penyakit ibu yang dapat mengakibatkan BBLR, memberikan penyuluhan tentang kebutuhan gizi saat hamil, meningkatkan penerimaan. Program Keluarga Berencana, menganjurkan istirahat yang cukup pada saat hamil

\section{KESIMPULAN}

Berdasarkan hasil penelitian yang telah dilakukan di RSKDIA Pertiwi Makassar, maka dapat ditarik kesimpulan penelitian antara lain: Ibu yang mengalami preeklampsia berat lebih banyak dibandingkan dengan ibu yang mengalami preeklampsia ringan, Ibu yang melahirkan bayi berat lahir rendah (BBLR) lebih banyak dari pada ibu yang melahirkan bayi berat lahir sangat rendah (BBLSR), lbu yang mengalami preeklampsia berat lebih banyak melahirkan bayi berat lahir rendah (BBLR), dan Dilihat dari kesimpulan diatas maka terdapat hubungan antara preeklampsia dengan kejadian bayi berat rendah di RSKDIA Pertiwi Makassar $(p 0.002 \leq 0,05)$

\section{SARAN}

Diharapkan kepada petugas kesehatan khususnya tenaga bidan agar dapat melakukan deteksi dini terjadinya pre eklamsi pada ibu hamil untuk mencegah terjadinya eklamsi berat sehigngga dapat menurunkan angka BBLR.

\section{UCAPAN TERIMA KASIH}

Terima kasih banyak kepada seluruh tenaga kesehatan yang membantu dalam pengambilan data sekunder dan kepada teman sejawat yang berpartisipasi dalam hasil penelitian ini

\section{DAFTAR PUSTAKA}

Auer.2010.Asuhan Neonatus Bayi dan Anak Balita. Jakarta: SalembaMedika

Badriyah, L., \& Tjahyani, E. (2013). HUBUNGAN ANTARA PREEKLAMPSIA BERAT DENGAN KEJADIAN BERAT BAYI LAHIR RENDAH. Akademi Kebidanan Griya Husada, (110).

Chamidah, A.N,. 2010. Asuhan Neonatus, Bayi, dan Anak Balita.Jakarta: Perpustakaan Nasional: Katalog Dalam Terbitan

Cunningham, F.G,. 2010. Obstetrics. Williams 23rd ed. USA : The McGraw-Hill Companies. Inc.

Depkes, RI. 2011. Model Safe Motherhood. Jakarta

Ika, Kun. 2012. Hubungan Antara Pre Eklampsi dengan Berat Badan Lahir Rendah (BBLR, Jurnal Ilmiah STIKES Perawatan Hang Tuah Surabaya Voulume 3 Nomor 2/April.

Mansjoer.2011. Buku Saku Manajemen Masalah Bayi Baru Lahir Panduan untuk Dokter, Perawat \& Bidan. Jakarta: EGC 
Jurnal Media Keperawatan: PoliteknikKesehatan Makassar

Vol. 11 No.012020

e-issn :2622-0148, p-issn : 2087-0035

Manuaba. 2010. Ilmu Kebidanan, Penyakit kandungan dan keluarga berencana untuk Pendidikan Bidan Edisi 2. Jakarta : EGC

Notoatmodjo. 2010. Metode Penelitian Kesehatan. Jakarta : Rineka Cipta

Nugroho, Taufan. 2012. Patologi Kebidanan. Yogyakarta : Nuha Medika

Padila. 2015. Asuhan Keperawatan Maternitas II. Yogyakarta : Nuha Medika

Pujiati Dewi, karwati, Mujiwati Sri 2013.Asuhan Kebidanan V (Kebidanan Komunitas).Jakarta : CV Trans Info Medika

Rahmawati, Titik. 2012. Dasar-Dasar Kebidanan. Jakarta:Prestasi Pustaka Publisher

Saifuddin. 2010. Buku Acuan Nasional Pelayanan Kesehatan Maternal dan Neonatal. Jakarta : Yayasan Bina Pustaka Sarwono Prawirohardjo

Setiawan A,S,. 2011. Metodologi Penelitian Kebidanan DIII, DIV, S1 Dan S2.Yogyakarta : Nuha Medika

Sudarti, Fauziah Afroh. 2013. Asuhan Neonatus Risiko Tinggi dan Kegawatdaruratan.Yogyakarta: Nuha Medika.

Suwoyo. 2011. Hubungan Preeklampsia dengan Kejadian bayi Berat lahir Rendah RSUD Dr.Hardjono Ponorogo

Wahyuni, S,. 2011. Hubungan Antara Preeklampsia Berat dengan Kejadian Berat Bayi Lahir Rendah

Wordpress.com. 2010. Kasus Bayi Berat Lahir Rendah di Sulsel 1,36\% dariJumlah

Yuni, A., Saryono, \& Kurniati, P. (2006). Hubungan antara preeklamsia pada primigravida dengan berat badan lahir rendah di rsud cilacap periode januari - desember 2005. Jurnal Keperawatan Soedirman (The Soedirman Journal of Nursing), 1(2), 91-95. 